DOI: http://doi.org/10,21009/JKKP.072.04

\title{
DISFUNGSI KELUARGA BURUH PABRIK di KELURAHAN KUTOREJO PASURUAN
}

\author{
Riski Ananda Putri ${ }^{\left.1{ }^{*} a\right)}$, Luluk Dwi Kumalasari ${ }^{1, b)}$, dan Aan Sugiharto ${ }^{1, c)}$ \\ ${ }^{1}$ Prodi Sosiologi Fakultas IImu Sosial dan IImu Politik Universitas Muhammadiyah Malang \\ Email : *a) riski.kian29@gmail.com, b) lux diva@yahoo.com, ${ }^{c}$ aansugiharto@umm.ac.id
}

\begin{abstract}
Abstrak
Penelitian ini mengkaji tentang adanya pergeseran fungsi di dalam keluarga yaitu fungsi yang menyebabkan beberapa sistem dalam struktur keluarga berubah mengakibatkan adanya disfungsi peran dalam anggota keluarga. Penelitian ini bertujuan untuk memperoleh data mengenai bagaimana disfungsi keluarga buruh pabrik di Kelurahan Kutorejo terjadi. Penelitian ini menggunakan pendekatan kualitatif dengan jenis penelitian deskriptif. Teknik penentuan subyek menggunakan purposive sampling. Sumber data yang digunakan yaitu data primer dan sekunder melalui catatan peneliti, foto, dokumen, buku maupun sumber tertulis lainnya. Adapun teknik pengumpulan data dengan observasi, wawancara dan dokumentasi. Penelitian ini menggunakan teori Struktural Fungsional oleh Robert K. Merton yaitu menekankan pada keteraturan atau order, ide yang digagas oleh Merton antara lain fungsi, manifest, fungsi laten dan disfungsi. Hasil penelitian ini menyatakan bahwa yang terjadi di dalam keluarga peran orang tua sangatlah penting karena dari orag tua anak mendapatkan pendidikan pertama dan yang utama. Namun, dikarenakan orang tua yang bekerja dan tidak berdaya untuk mengasuh anaknya sehingga fungsi-fungsi yang ada di dalam keluarga tidak berjalan sebagaimana mestinya. Yang terjadi ialah fungsi keluarga bergeser kepada orang lain, hal ini menunjukkan adanya disfungsi keluarga.
\end{abstract}

Kata kunci: Buruh Pabrik, Disfungsi, Keluarga

\section{DYSFUNCTION INDUSTRIAL WORKERS FAMILY IN DISTRICT KUTOREJO PASURUAN}

\begin{abstract}
This study examined the existence of a shift in family function, that caused the change of several systems in the family structure which resulting a role dysfunction of the family members. This study aimed to obtain the data of how the family dysfunction of factory workers in Kutorejo Village occurs. This research used a qualitative approach with descriptive research type. The technique of determining the subject using the purposive sampling. The data sources used were primary and secondary data through researchers' notes, photos, documents, books and other written sources. The data collection techniques by observation, interviews, and documentation. This research used Functional structural theory by Robert K. Merton that emphasizing the order, the ideas proposed by Merton including function, manifest, latent function, and dysfunction. The results of this study stated that family could not be separated from the role of the parents, the helplessness of the two parents who work as factory workers. requiring the functions that should be carried out shifted to other people, it made the main function of the family did not work as well. It indicated a dysfunction occured.
\end{abstract}

Keywords: Dysfunction, Factory Workers, Family 


\section{PENDAHULUAN}

Pendidik utama dan pertama bagi anak-anak mereka merupakan orang tua, dari merekalah anak pertama kali mendapatkan pendidikan. Dikatakan pendidik utama karena pendidikan dari orang tua menjadi dasar perkembangan dan kehidupan anak di kemudian hari hingga dibawa ke dunia bermasyarakat. Keluarga terdiri dari pribadi - pribadi yang berbeda menyesuaikan norma yang sudah diterapkan pada sistemnya. Keluarga yang terdiri dari ayah, ibu dan anak bisa disebut nuclear family (Rustina, 2014). Sedangkan keluarga luas yaitu extended family yang terdiri dari atas beberapa inti . Keluarga sebagai unit terkecil dari bagian masyarakat maka keluarga memiliki peran tertentu. Menurut soerjono Soekanto keluarga berperan sebagai pelindung atau pemelihara, memenuhi kebutuhan sosial ekonomi, dan pembelajaran tentang kaidah-kaidah dan nilai-nilai yang berlaku dalam masyarakat (Soekanto, 1992:23).

Keluarga memiliki hak dan kewajiban serta peran dan fungsi yang harus dijalankan oleh semua anggota keluarga (Suryadi, 2015:125). Seperti halnya ayah yang menjadi kepala keluarga yang harus menafkahi dan memberikan perlindungan. Ibu yang memiliki peran mendidik dan anak yang harus berbakti kepada orang tua serta belajar. Di dalam masyakat hak dan kewajiban dikenal sebagai hubungan peran (role relation). Seseorang akan disadarkan adanya hubungan peran karena sejak awal masa anak-anak sudah dikenalkan dengan proses sosialisasi (Subadi, 2008:20). Suatu situasi dimana anak akan belajar tentang apa yang dianggap baik oleh anggota keluarga. Menurut Willian J.Goode Keutamaan setiap keluarga adalah mempunyai fungsi untuk mengantar anak ke masyarakat besar. Sebagai penghubung pribadi dengan struktur sosial yang lebih besar (Goode, 1991:3).

Masyarakat Industri merupakan sekelompok individu yang mempunyai keterlibatan dalam kaitan teknologi, ekonimi dan perusahaan din sentral produksi. Input industri terhadap individu dalam masyarakat membentuk sikap dan tingkah laku yang tercermin dalam sikap bekerja. Oleh karena itu masyarakat industri memiliki nilai tertentu yang membentuk sikap dan tingkah laku dalam bekerja untuk mencapai tujuan hidup mereka. Dalam proses kehidupannya, mereka memiliki wawasan, sikap, mental dan nilai seperti menghargai waktu (Prasetyo dan sutopo, 2018:17).

Dari data Disnaker Jawa Timur tahun 2019 menunjukkan bahwa Kabupaten Pasuruan sebanyak 465 pabrik. Industrialisasi bisa dilihat dengan adanaya pengetahuan baru dalam ilmu dan teknologi dengan ciri penggunaan mesin dalam peroduksinya, menghasilkan sikap sekuler modern, cenderung anti tradisional, penempatan kerja berdasarkan keahlian. Kemajuan iptek dalam bidang industri menuntut tenaga kerja yang handal yang memiliki kemampuan dan etos kerja yang tinggi. Keadaan yang seperti itu melukiskan bahwa masyarakat industri menciptakan suatu suasana interaksi yang bersifat rasional dalam perilaku ekonomi dan sosial budaya. Ciri yang seperti ini jelas mempengaruhi suasana keluarga dalam lingkungan masyarakatnya.

Data disnaker Jawa Timur 2019 menjelaskan bahwa Kabupaten Pasuruan terdapat 465 perusahaan, di Kecamatan Pandaan terdapat 83 perusahaan sedangkan di Kelurahan Kutorejo merupakan daerah yang berada dalam lingkungan industri sebanyak 83 pabrik (Disnaker Jawa Timur. 2019). Dengan jumlah penduduk 4769 jiwa, pabrik dengan rekuitmen karyawan. Mayoritas penduduk kutorejo bekerja sebagai buruh di pabrik khususnya masyarakat lingkungan kutorejo untuk memenuhi kebutuhan sehari-hari yang lebih kompleks, tak heran jika banyak masyarkat yang bekerja di pabrik. 
Tabel 1. Daftar Perusahaan per-kelurahan / desa di Kecamatan Pandaan

\begin{tabular}{lc}
\hline No. Nama Kelurahan & Jumlah \\
\hline 1 Kelurahan Pandaan & 9 \\
2 Kelurahan Petungasri & 8 \\
3 Kelurahan Jogosari & 4 \\
4 Kelurahan Kutorejo & 12 \\
5 Desa Tawang Rejo & 8 \\
6 Desa Kebon Waris & 0 \\
7 Desa Karang Jati & 9 \\
8 Desa Plintahan & 2 \\
9 Desa Durensewu & 2 \\
10 Desa Wedoro & 0 \\
11 Desa Tunggul Wulung & 0 \\
12 Desa Sumber Gedang & 6 \\
13 Desa Nogosari & 6 \\
14 Desa Sebani & 0 \\
15 Desa Banjarsari & 0 \\
16 Desa Banjar Kejen & 0 \\
17 Desa Kemiri Sewu & 9 \\
\hline Desa Sumber Rejo & 5 \\
\hline
\end{tabular}

Berdasarkan Soedjipto Sosrodiharjo juga mengungkapkan bahwa keluarga sebagai bagian dari masyarakat, sehinga sangat terpengaruh oleh masyarakat di sekelilingnya (Sosrodiharjo, 1991:134). Misalnya, perubahan yang disebabkan oleh perubahan revolusi industri yang mempengaruhi keluarga. Demikian juga dengan industrialisasi, pada umunya mempengaruhi keadaan keluarga. Industrialisasi sedikit banyak membawa pengaruh bagi pola kehidupan keluarga, secara tidak disadari dapat menimbulkan perubahan-perubahan yang cukup mendasar terhadap struktur dan nilai sosial dalam keluarga.

Proses sosial yang terjadi begitu mekanis dan instrumental sebab individu pada masyarakat selalu mengikuti perkembangan jaman. Pada abad ini begitu banyak penemuan perangkat teknologi khususnya media komunikasi dan informasi yang secara tidak langsung berdampak pada pengaruh peran dan fungsi keluarga (Prasanti, 2016).

Menurut Rachaniningsih (2014) Pergeseran fungsi menyebabkan adanya disfungsi dalam keluarga. Hal ini dapat dilihat dalam realita di Kabupaten Pasuruan tepatnya di Kelurahan Kutorejo sebelum tahun 2007 tipologi masyarakat agraris akan tetapi, pada tahun 2007 terdapat banyak pabrik di pasuruan dan tetapkan sebagai kawasan industri pada tahun 2007 karena adaanya PIER (Agustini and Winarni, 2014). Sehingga pada tahun 2007 mengalami peningkatan penduduk serta perekonomian mulai berkembang. Perkembangan industri sangat berkembang dengan pesat di wilayah pasuruan salah satunya yaitu di kelurahan kutorejo kecamatan pandaan dan berdampak pada fungsi-fungsi keluarga.

Realitas pada masyarakat Kelurahan Kutorejo sebanyak 1.026 jiwa dari 4.769 jiwa yang bekerja sebagai buruh pabrik atau pegawai swasta. Dikarenakan orang tua bekerja di pabrik maka banyak hal yang membuat orang tua tidak memperhatikan anaknya, salah satu 
kesibukan orang tua dan orang tua menganggap anaknya sudah besar dan sudah bisa membedakan mana yang salah dan benar. Pada tahun 2015 realitas sudah tampak karena orang tua bekerja, melakukan kesibukan mereka untuk mencari materi.

kurang peduli dengan kondisi mental, psikologis dari anak-anak mereka sendiri. Sehingga terjadi pembiaran dan mengakibatkan anak yang susah diatur seperti jarang pulang karena ikut mengamen, putus sekolah dan ngaji. Pembiaran tersebut merupakan disfungsi keluarga karena orang tua seringkali tidak terlibat secara langsung dalam hal mengasuh, mendidik, membesarkan dan seringkali hidup terpisah dari anak-anak mereka. Untuk mewujudkan keberhasilan yang diingkinkan maka modal utama yang harus dimiliki setiap individu ialah kerjasama agar dapat bertahan menghadapi perkembangan zaman (Talopo, Pribadi, and Topan, 2018).

Oleh karena itu Penelitian ini dirasa penting oleh peneliti karena ingin melihat bagaimana disfungsi keluarga pada masyarakat industri dalam menjalankan fungsi-sungsi tersebut. Berdasarkan latar belakang yang telah diuraikan, maka dalam penelitian ini peneliti menarik judul "Disfungsi Keluarga Buruh Pabrik Di Kelurahan Kutorejo Pasuruan".

\section{METODE}

Penelitian ini menggunakan pendektatan kualitatif dengan data yang dikumpulkan berupa kata-kata atau gambar yang dipaparkan oleh narasumber. Jenis penelitian yang digunakan yaitu deskriptif karena mendeskripsikan secara terperinci mengenai disfungsi keluarga buruh pabrik. Lokasi penelitian berada di Kelurahan Kutorejo alasan dipilih lokasi penelitian yaitu terdapat industri dan keluarga mengalami disfungsi. Teknik penentuan subyek yang digunakan yaitu Purposive Sampling dimana peneliti memiliki kriteria sebagai subyek yaitu yang pertama keluarga yang memiliki anak, yang kedua orang tua yang bekerja sebagai buruh pabrik, yang ketiga yaitu Keluarga yang mengalami disfungsi. Jumlah subyek yang didapatkan adalah sebanyak 17 orang (4 keluarga dan 2 aparatur desa). Teknik pengumpulan data yang digunakan yaitu Wawancara, Observasi dan Dokumentasi. Sumber data yang digunakan berupa data primer yang diperoleh peneliti secara langsung melalui wawancara dan obsevasi sedangkan data sekunder diperoleh tidak langsung berupa dokumentasi atau foto dari informan dan teknik analisa data yaitu pengumpulan data, Reduksi data, penyajian data, dan penarikan kesimpulan (Lian, Kristiawan, \& Fitriya, 2018).

\section{HASIL DAN PEMBAHASAN}

Analisi pertama dilakukan dengan melihat kondisi keluarga buruh. Sebagian keluarga yang menjadi buruh yaitu suami istri atau ayah ibu. Yang pertama yaitu keluarga Bapak Arif (49) dan Ibu Khasanah (47) memiliki 4 orang anak. Yang kedua keluarga Bapak Suki (42) dan Ibu Siti (38) memiliki 1 anak. Yang ketiga Bapak Fery (31) dan lbu Yuni (29) memiliki 1 anak. Yang keempat yaitu Bapak Arlan (48) dan Ibu Didin (47) memiliki 1 anak.

Orang tua yang berprofesi sebagai buruh pabrik, menghabiskan banyak waktunya selalu di pabrik, sehingga orang tua sangat terbantu dengan adanya lembaga serta pengasuh baik itu nenek, tante maupun orang lain yang dipekerjakan untuk menjaga anaknya hingga tetangga, karena beban tanggung jawab yang besar untuk anaknya. Sehingga bertanggung jawab atas pendidikannya untuk menyekolahkan dan memberikan fasilitas yang baik. Dengan demikian orang tua yang bekerja sama dengan sekolah maupun pengasuh agar membentuk akhlak anak menjadi baik. Jika dirumah anak diajarkan untuk memahami sesuai dengan jenis kelaminnya.

Ibu Yuni memberikan waktu pada anaknya untuk menanamkan nilai norma pada saat dirumah dikarenakan anak Ibu Yuni berusia 8 tahun, lain halnya dengan Bapak Suki yang penanaman nilai norma namun lebih di bebankan kepada tante atau anggota keluarga lain, 
Bapak suki beranggapan bahwa anaknya sudah mengerti apa yang harus dilakukan sehingga tidak memberikan penanaman nilai dan norma.

Buruh pabrik adalah salah satu lingkungan kerja yang keras, dapat dilihat dari keseharian orang yang bekerja di pabrik yang dari pagi sampai malam terus bekerja untuk mengejar setoran serta perilaku yang kurang baik akan tetapi jika sudah di dalam keluarga, mereka tidak ingin anaknya mendapar perilaku yang sudah dialami oleh orang tua. Kewajiban orang tua memberikan kehidupan yang layak untuk anggota keluarganya sehingga rela bekerja di pabrik.

Memberikan sandang pangan dan papan serta fasilitas pendidikan dan pengawasan dibebankan oleh orang lain dikarenakan orang tua yang sibuk bekerja sehingga terjadinya disfungsi dari fungsi-fungsi yang tidak bisa dijalankan dengan baik oleh orang tua. Walaupun waktu yang dimiliki oleh orang tua dalam mendidik atau bisa dikatakan dibebankan kepada orang lain, namun mereka berusaha untuk memberikan waktu untuk berkumpul dan berbincang-bincang dengan anak-anaknya.

\section{Disfungsi Keluarga Buruh Pabrik}

Dari tugas dan kewajiban keluarga diketahui terjadinya disfungsi di dalam keluarga karena tidak berjalannya fungsi-fungsi dalam keluarga antara lain disfungsi terhadap sikap yang sesuai dengan norma yang berlaku dalam masyarakat, tidak berjalannya fungsi dalam bidang keagamaan, serta kurang diterapkannya fungsi cinta kasih dari orang tua untuk anaknya, dan atau telah gagal fungsi dalam pendidikan. Hal tersebut bisa terjadi karena perubahanperubahan dalam masyarakat, terutama perubahan tipologi masyarakat yang sebelumya adalah masyarakat agraris berubah menjadi masyarakat industri, terutama setelah tahun 2007.

Sektor industri yang berkembang semakin cepat dikarenakan era globalisasi ekonomi yang disertai dengan pesatnya perkembangan teknologi. Pembangunan industri bertujuan untuk meningkatkan kesejahteraan masyarakat, untuk mencapai kualitas hidup yang lebih baik. Keberadaan suatu industri dapat meningkatkan pertumbuhan ekonomi karena dapat membuka peluang pekerjaan yang seluas-luasnya.

Wilayah Kelurahan Kutorejo Pasuruan merupakan salah satu daerah yang memiliki banyak industri, mulai dari pabrik kayu, pabrik kertas, pabrik sepatu, pabrik rokok, pabrik makanan hingga pabrik minuman. Banyaknya industri yang berkembang di wilayah Kelurahan Kutorejo membuat masyarakat melangkang maju dengan menerima berbagai perubahan yang dialami. Profesi masyarakat Kelurahan Kutorejo sangat beragam seperti, petani, peternak sapi, berwirausaha membuka toko, bengkel, kue. Namum banyak masyarakat kelurahan Kutorejo memilih menjadi buruh dikarenakan menginginkan gaji yang tetap.

Bentuk tidak langsungnya yaitu hubungan antara pekerja dan keluarga terjadi melalui keanggotaan dalam kelas sosial sehingga seseorang yang mendapatkan pekerjaan sekaligus juga akan mendapatkan suatu tingkat sosial tertentu yang sering ditunjukkan pada sikap dan perilaku tertentu (Jannah and M. Ridwan Said Ahmad, 2018). Keberadaan pabrik membuat secara tidak langsung juga mempengaruhi sebuah keluarga pada peran dan fungsi yang dimiliki setiap anggota keluarga. orang tua atau suami istri yang sibuk bekerja berorientasi dengan uang akan berfikir secara praktis memberikan fasilitas kepada anak mereka dan akhirnya fungsi yang dimiliki setiap anggota bergeser pada orangtua/nenek, tante maupun asisten rumah tangga yang mereka miliki.

Sosialisasi yang diberikan oleh nenek, tante maupun asisten rumah tangga adalah bentuk sosialisasi yang seharusnya bukan menjadi dasar yang diberikan anak, namun keluargalah yang menjadi dasar untuk menentukan perkembangan anak nantinya. Namun pada kenyataannya orang lain yang menerapkan sosialisasi seperti penanaman nilai dan norma pada keluarga, mengawasi dan mengendalikan secara wajar agar anak tidak merasa tertekan, memberikan bekal pendidikan ilmu agama. Orang tua hanya memfasilitasi apa yang dibutuhkan anak tanpa ada arahan dari orang tua melainkan arahan orang lain. 
Orang tua banting tulang untuk bekerja demi anaknya tidak mengeluh karena orang tua memiliki motivasi yang tinggi dalam menyejahterahkan keluarganya. Orang tua yang berprofesi sebagai buruh pabrik ditekan di setiap pekerjaannya, dituntut untuk sempurna dalam bekerja serta dituntut untuk mencapai target yang ditentukan oleh pabrik. Pekerja buruh baprik bekerja tanpa ada waktu luang untuk bersantai, bahkan jika target mereka belum terpenuhi maka akan diberikan jam tambahan untuk bekerja, yang sering disebut dengan jam lembur.

Jam kerja dan sistem kerja di pabrik memang cukup berat, tetapi itulah satu-satunya pilihan yang bisa dilakukan untuk menjaga perekonomian keluarga tetap stabil. Ada dorongan semangat orang tua yang bekerja sebagai buruh pabrik untuk selalu sabar dan tegar demi mensejahterahkan keluarganya. Faktor orang tua yang bekerja di pabrik karena tidak ada pilihan lain untuk mendapatkan penghasilan tetap dan juga tempat tinggal yang dekat dengan wilayah pabrik.

Uang transport yang mereka keluarkan tidak dan pada saat istirahat mereka bisa pulang untuk makan sehingga lebih hemat. Namun di lain sisi, Bapak Suki dan Ibu Siti mereka juga memikirkan anak-anaknya dengan bekerja mereka dapat memenuhi kebutuhannya sehingga pada saat mereka bekerja anak mereka dititipkan pada orang lain untuk dijaga. Keberada orang lain ini seperti nenek, tante bahkan asisten rumah tangga. Mereka juga mengajarkan nilai dan norma hampir sama yang diajarkan oleh keluarga seperti memberikan peringatan saat anak melakukan kesalahan dan mengajarkan untuk mengerjakan tugas dari sekolah.

Orang lain yang membantu dalam pendidikan serta penanam nilai dan norma anak untuk menjalankan fungsi yang seharusnya dilakukan oleh keluarga, menjadi tidak berfungsi karena dilakukan oleh orang lain sehingga bisa disebut dengan disfungsi. Disfungsi adalah keadaan fungsi keluarga yang tidak dapat berjalan dengan baik, karena fungsi tersebut dilakukan oleh orang lain dalam penelitian ini orang tua yang sibuk bekerja untuk memenuhi kebutuhan keluarganya atau demi kesejahteraan keluarganya.

\section{Bentuk Disfungsi Yang Terjadi Pada Keluarga Buruh}

Dari observasi penulis dan beberapa sumber yang didapatkan dari krlurahan yaitu dari $1636 \mathrm{KK}$ dan 1.026 bekerja sebagai buruh pabrik. Data dari ketua ketua RW di 5 Lingkungan/Dusun mengalami disfungsi 69 KK. Dari 69 KK tersebut buruh pabrik yang ada di Kelurahan Kutorejo mengalami disfungsi keluarga, Penyebab orang tua yang bekerja menjadi alasan yang utama terjadinya disfungsi keluarga buruh pabrik terdapat beberapa disfungsi yang ditemukan di lapangan.

Yang pertama pada keluarga Bapak Arif dan Ibu Khasanah dikarenakan sibuk bekerja menjadikan anak ketida dan keempatnya menjadi tidak terurus dan tidak bisa mengurus anak dengan baik sehingga bentuk disfungsi yang terjadi adalah gagalnya dalam pendidikan formal pada anak ketiga dan keempat, anak ketiga tidak mau sekolah hingga putus sekolah dan dibiarkan saja oleh kedua orang tuanya, dan yang ke tiga anaknya tidak mengerti bagaimana menghormati orang lain terutama pada orang tuanya sendiri.

Yang kedua pada Keluarga Bapak Suki dan Ibu Siti dikarenakan mereka sibuk bekerja sehingga fungsi yang seharusnya dijalankan oleh kedua orang tua bergeser pada nenek dan tantenya. Karena tidak bisa mengurus anak dengan baik sehingga terjadi disfungsi keluarga yang terjadi anak tidak terlalu dekat dengan orang tua sehingga anak berbuat semaunya sendiri dan juga sering membolos sekolah dalam hal pendidikan formalnya, pergi tanpa izin, serta mencari kebahagiaaan bersama teman-temannya dan tidak pulang untuk beberapa hari.

Yang ketiga pada keluarga Bapak Feri dan Ibu Yuni dikarenakan mereka sibuk bekerja maka mempekerjakan pengasuh untuk anaknya, sehingga fungsi uang seharusnya dijalankan oleh orang tua dibebankan kepada pengasuhnya. Fungsi menjaga, memberikan kasih sayang, fungsi pendidikan, jika pendidikan dibebankan pada guru sekolah maupun guru bimbingan belajarnya. Sehingga menjadi anak yang ceria jika diluar karena memiliki banyak teman, 
namun jika sudah dirumah menjadi anak pendiam dan lebih menurut dan lebih dekat dengan pengasuhnya.

Yang kempat pada Keluarga Bapak Arlan dan Ibu Didin dikarenakan kesibukan orang tua juga keretakan keluarga sehingga membuat lbu Didin menjadi orang tua tunggal yang mengurus anak mereka, Ibu Didin yang bekerja sendiri untu memenuhi kebutuhan dirinya serta anaknya menitipkan anak pada saudaranya. Disfungsi yang terjadi akibat keretakan keluarga serta Ibu Didin yang tidak bisa mengurus anaknya menjadi kurang dekat dengan anaknya, tidak bisa mendidik dan memberikan pengarahan nilai norma pada anak, sehingga yang memberikan pengarahan serta nilai norma adalah saudaranya. Anaknya menjadi tidak bisa mengembangkan dirinya sehingga yang terjadi sering murung, sedih dan menangis takut untuk bersosialisasi dengan orang luar serta takut untuk memulai hal baru.

\section{Penyebab Terjadinya Pergeseran Fungsi Keluarga}

\section{Kesibukan Kedua Orang Tua Yang Bekerja}

Orang tua adalah komponen terpenting sebuah keluarga dalam hal mengasuh, memberikan pemahaman dan memenuhi kebutuhan untuk anaknya (Indrawati, 2014). Keluarga terdiri dari pribadi-pribadi yang merupakan bagian dari jaringan sosial yang lebih besar. Oleh karena itu tugas-tugas keluarga merupakan tanggung jawab langsung setiap pribadi dalam masyarakat (Rochaniningsih, 2014). Keluarga yang baik yaitu keluarga memiliki hubungan yang sangat erat antara ibu, ayah dan anaknya atau anggota keluarga. Orang tua bagi anak adalah seorang panutan sehingga anak akan cenderung mengikuti perilaku orang tua, jika anak diarahkan pada hal baik maka menjadi baik. Anak akan sangat menghormati orang tuanya dan akan selalu mereka butuhkan. Seiiring kemajuan zaman yang semakin modern dan kebutuhan akan ekonomi semakin meningkat juga semikin besar membawa pengaruh terhadap keluarga tentang struktur peran dan fungsi anggota keluarga (Agustin dkk., $2015: 46)$.

Kebutuhan dalam hal perekonomian yang dibuthkan sangat besar sehingga kedua orang tua harus untuk bekerja (Mulyadi, 2015 : 311). Dahulu ibu berkesempatan penuh untuk mengasuh dan bimbingbing anaknya, namun kamrena desakan ekonomi hal ini menjadikan seorang ibu harus ikut terjun dalam dunia kerja. Keadaan orang tua yang bekerja saat ini menjadi semakin sibuk dengan pekerjaan mereka dan sudah tidak bisa lagi memenuhi fungsi dan kebutuhan akan kasih sayang serta peran yanag seharusnya didapatkan anak secara utuh.

Terkadang aktifitas bekerja para orang tua pun tidak mengenal waktu, sehingga membuat mereka sulit mendapatkan kesempatan bersama anak. Dari hal tersebut, peran-peran orang tua seperti pengawasan, fungsi afeksi, ekonomi, agama, dan pendidikan sedikit mengalami perubahan, karena para orang tua yang terlalu sibuk meskipun pada dasarnya hal tersebut diperuntukkan bagi anaknya, namun beberapa peran penting yang seharusnya menjadi kewajiban orang tua yang menjadi bergeser atau bahkan hilang (Solikhah dan Mudzakkir, 2015)

Pekerjaan orang tua Bapak Fery dan Ibu Yuni sebagai buruh pabrik mejadikan orang tua memberikan tanggung jawab kepada orang lain seperti nenek, tante dan pengasuhnya. Pengaruh kesibukan orang tua menyebabkan orang tua kurang bisa mengasuh dan mendidik anak di rumah, sehingga mereka harus meminta bantuan orang lain untuk menggantikan fungsi yang seharusnya dijalankan oleh orang tua. Kedua orang tua bekerja supaya memenuhi fungsi lainya seperti fungsi ekonomi keluarga tanpa mengabaikan anak walaupun harus dijalankan dengan tidak utuh.

\section{Tuntutan Zaman}

Pesatnya perubahan zaman mempengaruhi berbagai sektor dalam kehidupan (Hermawati, 2018 : 26). Keluarga menjadi suatu hal yang terpengaruh oleh perkembangan 
zaman yang semakin maju. Zaman semakin modern inilah manusia selalu dituntut untut untuk selalu kreatif dan aktif supaya tidak kurang informasi ataupun hal yang menunjang kemajuan hidupnya. Hal ini mengharuskan orang tua memiliki nilai dan norma yang harus ditanamkan kepada anaknya dan juga memilih prinsip yang kokoh supaya tidak goyah dengan berita simpang siur yang beredar di masyarakat dan ketrurunan menjadi orang yang bisa mengikuti arus zaman modern dengan sikap yang positif.

Tuntutan zaman yang semakin berkembang menjadikan anak harus tumbuh pada zamannya, mengenal teknologi agar anak yang tumbuh tidak kudet dengan alat elektronik dan memiliki bekal yang baik agar di masa depan dapat menghadapi zaman yang serba instan supaya tidak terjerumus ke hal yang negatif.

Keadaan yang seperti ini orang tua menjadi harus ekstra dalam hal medidik anaknya dengan baik, namun keadaan tersebut kebanyakan timpang karena keadaan orang tua yang tidak bisa mendidik anaknya dengan baik (Rahmaita, dkk, 2016 : 1). Realitas permasalahan di zaman modern yang semakin makutkan maka orang tua menitipkan anaknya kepada nenek, tante maupun orang lain seperti tetangga supaya ada yang mengawasi anaknya. Orang tua yang tidak dapat mendidik anaknya di zaman yang mendesak membuat bimbang akan pendidikan yang diterapkan di rumah sehingga mereka memilih untuk mndaftarkan pada lembaga TPQ, sekolah formal maupun pada bimbingan belajar atau les yang sekiranya dapat membantu persoalan keluarga.

Dilihat dari Perspektif dalam sosiologi keluarga dengan teori struktural fungsional oleh Robert K. Merton dalam Siswanto (2007) tentang disfungsi dapat dilihat dari aspek fungsi, disfungsi, fungsi manifest dan fungsi laten. Fungsi sendiri yang dimaksud yaitu peran yang dimiliki setiap anggota keluarga yang harus dijalankan seperti fungsi memenuhi kebutuhan, fungsi melindungi, fungsi, cint kasih, fungsi agama, fungsi sosial budaya, fungsi pendidikan dan fungsi lingkungan, jika fungsi tersebut tidak dijalankan dengan baik maka akan terjadinya disfungsi. Disfungsi yaitu keadaan suatu sistem keluarga terpecah dan keluarga yang merupakan unit terkecil dari masyarakat anggotanya tidak atautelah gagal menjalankan fungsifungsi secara normal.

Realitas pada masyarakat Kelurahan Kutorejo Pasuruan mayoritas masyarakatnya bekerja sebagai buruh pabrik, karena pabrik di wilayah Kelurahan Kutorejo sebanyak 92 pabrik dengan penyerapan tenaga kerja hingga ratusan. Keluarga yang tinggal di Kelurahan Kutorejo memilih untu bekerja di pabrik karena memiliki gaji tetap. Keluarga yang terdiri dari suami istri atau ibu ayah sama-sama bekerja pada pabrik sebagai buruh dengan alasan untuk memenuhi kebutuhan ekonomi keluarga, sehingga seorang istri atau ibu membantu pemenuhan kebutukan ekomomi. Dengan seorang istri atau ibu yang bekerja sebagai buruh pabrik maka fungsi keluarga yang semula memberika perlindungan, memendidik anak, menanamkan nilai norma, memberikan cinta kasih dan agama pada anak fungsi tersebut dialihkan pada nenek, tante maupun orang lain seperti tetangga dan pengasuh sehingga fungsi yang tidak dijalankan tersebut mengalami disfungsi.

Robert K. Merton Robert K. Merton dalam teori nya membagi fungsi menjadi fungsi manifest (intended) dan fungsi laten (unintended). Fungsi manifest sosialisasi keluarga yaitu memebrikan pendidikan, mengajarkan norma terhadap anak. fungsi manifest keluarga yaitu memberikan pemahaman, menjelaskan atau mensosialisasikan kepada anak supaya anak memiliki moral, sehingga keluarga bertanggung jawab dengan fungsinya sebagai pemelihara tatanan (Merdiyati, 2015 : 453). Namun, jika dalam sebuah keluarga jika sudah tidak ada lagi fungsi manifest dan sosialisasi moral pada anak bukan lagi menjadi sebuah perhatian khusus maka akan menjadikan sebuah disfungsi dalam keluarga. Seperti orang tua yang sibuk bekerja sehingga anak di titipkan pada tetangga maupun pengasuh, neneh atau tante.

Robert K. Merton menjelaskan bahwa akibat atau konsekuensi yang tidak diharapkan ini tidak sama dengan fungsi yang tersembunyi. Fungsi tersembunyi adalah satu jenis dari akibat yang tidak diharapkan, satu jenis yang fungsional untuk sistem tertentu. Terdapat dua tipa dari 
akibat yang tidak diharapkan, yang disfungsional untuk sistem tertentu dan terjadi dari disfungsi yang tersembunyi dan yang tidak relevan dengan sistem yang dipengaruhinya, baik secara fungsional maupun disfungsional.

Realitas pada keluarga tempat peneliti mengadakan penelitian terdapat fungsi laten atau fungsi tersembunyi, yaitu ketika sebuah tujuan yang menjadi harapan keluarga yang ada di Kelurahan Kutorejo Pauruan. Dimana keluarga, ibu ayah ataupun istri suami yang bekerja sebagai buruh pabrik dan tujuan tidak tercapai, seperti bekerja demi memenuhi kebutuhan anak, agar anak bisa sekolah namun yang terjadi, anak yang tidak mendapatkan pengarahan sosialisasi yang baik merasa tertekan dengan dia bersekolah menjadikan alasan berangkat sekolah namun tidak berangkat sekolah melainkan untuk mengamen bersama temannya.

Teori atau pendekatan yang digunakan yaitu Fungsional Struktural mulai berkembangan yang dilakukan oleh antropolog dan sosiolog pada awal abad ke-20 sampai tahun 1960-an yang saat ini masih digunakan untuk kerangka konseptial yang berpengaruh dapat digunakan dalam kajian keluarga menurut Leslie dan Koman (Ihromi, 2004:269). Teori yang memandang bahwa lapisan pada masyarakat adalah suatu struktur yang baik, norma dan berjalan sesuai dengan fungsinya serta tidak menghendaki konflik walaupun nyatanya tidak ada perubahan tanpa adanya konflik dan konsep utama yang di-gagas oleh Robert K. Merton yaitu fungsi, disfungsi, fungsi laten, fungsi manifest dan keseimbangan. Asumsi dasar pada teori fungsionalisme struktural ini adalah setiap struktur dalam sosial dan berfungsi dengan sebagaimana fungsiya jika tidak maka akan hilang dengan sendirinya.

Teori ini memusatkan pada keteraturan dalam keluarga juga struktur yang ada di masyarakat, keteratutan yang diakibatkan keberagaman fungsi dalam sistem sosialnya. Fungsi di antara sruktur sosial kemudian menjadi salah satu dasar untuk melihat adanya potensi konflik sosial. Maka dari itu Robert K. Merton menganggap bahwa konflik sosial memang terjadi akibat suatu fungsi yang tidak berjalan disebut anomie. Bahwa anomie yang terjadi di setiap keluarga pada masyarakat dikarenakan adanya kebutuhan sosial yang meningkat (Ritzer, 2007:21).

Teori Struktural fungsionalisme Robert K. Merton menekankan pada keteraturan (order) dan mengabaikan konflik dan perubahan dalam masyarakat. Konsep utamanya adalah fungsi, disfungsi, fungsi laten, fungsi manifest dan keseimbangan (equilibrium) (Ritzer, 2007:21). Menurut teori ini bahwa keluarga merupakan bagian terkecil dari masyarakat merupakan makhluk yang berkaitan satu sama lain dan manusia merupakan bagian yang tidak bisa terlepas dari bantuan orang lain sehingga menyatu dalam keseimbangan.

Fungsi adalah akibat yang dapat diamati menuju adaptasi atau penyesuaian diri dalam suatu sistem. Keluarga merupakan bagian dari sistem sosial bangsa unit terkecil dari bagain masyarakat yang dapat diamati oleh seseorang. Tugas seorang keluarga yaitu menjalankan yang sesuai dengan fungsinya. Keluarga yang dari dulu sampai sekarang telah menjadi kaca pembesar di dunia sosial, karena semua yang terjadi di masyarakat berawal dari keluarga sehingga keluarga harusnya menjalankan fungsi setiap anggota keluarga dengan baik sesuai dengan perannyanya.

Sebagaimana selaras dengan penelitian ini yaitu tentang disfungsi sosialisasi keluarga buruh pabrik di Kelurahan Kutorejo Pasuruan dimana setiap anggota keluarganya memiliki fungsi berbeda yang harus dijalankan. Seperti ayah yang mencari nafkah, mendidik anaknya meskipun tidak sepenuhnya, ibu yang mendidik anak-anaknya, memberikan sosialisasi penanaman nilai norma, pendidikan, agama dan cinta kasih. Anak yang seharusnya membantu orang tua menjadi anak yang baik, belajar tekun dan berguna bagi keluarga dan bangsa. Namun pada kenyataannya keluarga yang kedua orang tuanya bekerja, ibu dan ayahnya bekerja sebagai buruh pabrik tidak bisa menjalankan fungsi sebagaimana mestinya, sehingga fungsi cinta kasih, penanaman nilai norma, pendidikan dan agama harus dibebankan kepada orang lain maka fungsi tersebut tidak jalan sehingga disebut dengan disfungsi. 
Disfungsi merupakan salah kemacetan keadaan dimana fungsi tidak dijalankan sebagaimana mestinya.

Realitas pada masyarakat Kelurahan Kutorejo Pasuruan mayoritas masyarakatnya bekerja sebagai buruh pabrik, karena pabrik di wilayah Kelurahan Kutorejo sebanyak 92 pabrik dengan penyerapan tenaga kerja hingga ratusan. Keluarga yang tinggal di Kelurahan Kutorejo memilih untu bekerja di pabrik karena memiliki gaji tetap. Keluarga yang terdiri dari suami istri atau ibu ayah sama-sama bekerja pada pabrik sebagai buruh dengan alasan untuk memenuhi kebutuhan ekonomi keluarga, sehingga seorang istri atau ibu membantu pemenuhan kebutukan ekomomi. Dengan seorang istri atau ibu yang bekerja sebagai buruh pabrik maka fungsi keluarga yang semula memberika perlindungan, memendidik anak, menanamkan nilai norma, memberikan cinta kasih dan agama pada anak fungsi tersebut dialihkan pada nenek, tante maupun orang lain seperti tetangga dan pengasuh sehingga fungsi yang tidak dijalankan tersebut mengalami disfungsi.

Robert K. Merton mengemukakan diteorinya bahwa fungsi terbagi menjadi dua yaitu fungsi manifest (intended) dan fungsi laten (unintended). Pada pengembangan pemahaman fungsi manifest dalam sosiologi sering kali terpengaruh oleh ilmu biologi, seperti halnya panca indra yang ada di tubuh manusia, panca indra memiliki fungsi masing-masing biologis. Sehingga mengacu kepada fungsi ini tentunya dapat dikaitkan bahwa keluarga memiliki fungsi reproduksi dan sosialisasi. Jadi fungsi reproduksi keluarga sebagai pembuat keturunan, maka fungsi manifest keluarga yaitu memebrikan pendidikan, pemahaman norma kepada anak.

Teori terfokus pada persoalan dimana fungsi manifest keluarga yaitu memberikan pemahaman, menjelaskan atau mensosialisasikan kepada anak supaya anak memiliki moral, sehingga keluarga bertanggung jawab dengan fungsinya sebagai pemelihara tatanan. Namun, jika dalam sebuah keluarga jika sudah tidak ada lagi fungsi manifest dan sosialisasi moral pada anak bukan lagi menjadi sebuah perhatian khusus maka akan menjadikan sebuah disfungsi dalam keluarga. Seperti orang tua yang sibuk bekerja sehingga anak di titipkan pada tetangga maupun pengasuh, neneh atau tante.

Tingkat mensosialisasikan norma moral, pendidikan dan agama akan berbeda dengan yang masih keluarga. anak yang hanya dititipkan pada tetangga memiliki disfungsi lebih besar, seperti pada keluarga Ibu Khasanah dan Bapak Arif dimana anak ketiga yang seharusnya masih duduk di bangku Sekolah Menengah Pertama (SMP) sudah tidak mau bersekolah lagi dikarena memang dari dirinya sendiri yang sudah tidak mau sekolah dan orang tuanya pun membiarkan anaknya tidak bersekolah.

Robert K. Merton memberikan pendapat pada sebuah institusi sosial dimana mereka memiliki fungsi yang bersifat laten (tidak diharapkan) dan dengan beberapa motif-motif eksplisitnya. Robert K. Merton menjelaskan bahwa akibat atau konsekuensi yang tidak diharapkan ini tidak sama dengan fungsi yang tersembunyi. Fungsi tersembunyi adalah satu jenis dari akibat yang tidak diharapkan, satu jenis yang fungsional untuk sistem tertentu. Terdapat dua tipa dari akibat yang tidak diharapkan, yang disfungsional untuk sistem tertentu dan terjadi dari disfungsi yang tersembunyi dan yang tidak relevan dengan sistem yang dipengaruhinya, baik secara fungsional maupun disfungsional.

Realitas pada keluarga yang menjadi subyek peneliti untuk penelitian terdapat fungsi laten atau fungsi tersembunyi, yaitu ketika sebuah tujuan yang menjadi harapan keluarga yang ada di Kelurahan Kutorejo Pauruan. Dimana keluarga, ibu ayah ataupun istri suami yang bekerja sebagai buruh pabrik dan tujuan tidak tercapai, seperti bekerja demi memenuhi kebutuhan anak, agar anak bisa sekolah namun yang terjadi, anak yang tidak mendapatkan pengarahan sosialisasi yang baik merasa tertekan dengan dia bersekolah menjadikan alasan berangkat sekolah namun tidak berangkat sekolah melainkan untuk mengamen bersama temannya.

Keluarga menyekolahkan anak dengan tujuan dan motif agar anak mendapat sosialisasi pendidikan dan agama yang tidak di diberikan di dalam keluarga dan aak memiliki norma, nilai 
dan moral yang baik. Namum kenyataannya anak belum bisa menghantarkan pada harapan dalam tujuan keluarga.

\section{SIMPULAN DAN SARAN}

Hasil penelitian yang dikaitkan dengan disfungsi dan pekerja buruh parik maka disfungsi merupakan keadaan sebuah sistem keluarga yang terpecah apabila salah satu atau lebih dari anggota keluarga tidak dapat menjalankan tugas dan fungsinya. Sehingga, menyebabkan terjadinya keluarga yang disfungsi yaitu tidak bisa menjlankan fungsinya dengan baik. Keluarga disfungsi merupakan bagian terkecil dari masyarakat, dimana sistem sosial terkecil ini tidak atau telah gagal menjalankan fungsi secara normal. Hubungan yang terjalin tidak berjalan dengan harmonis dan masih-masing anggotanya tidak jelas fungsi atau ikatan emosi antar keluarga kurang terjalin dengan baik.

Disfungsi pada keluarga yang ada di Keluraha Kutorejo Kabupaten Pasuruan terjadi akibat faktor ekonomi dan juga perkembangan industri yang sangat pesat. Disfungsi yang terjadi dikarenakan orang tua yang harus bekerja sebagai buruh pabrik untuk memenuhi kebutuhan sehati-hari anggota keluarga sehingga orang tua menitipkan anak mereka pada anggota keluarga yang lain seperti nenek, tante maupun pengasuh atau tetangganya. Dengan melihat peranan-peranan yang ada di dalam keluarga menjadikan adanya proses interaksi antara orang tua dan anak tidak terlalu dekat sehingga tidakada ikatan emosional yang terjadi.

Berdasarkan hasil penelitian terdapat beberapa saran keluarga atau orang tua baik istri maupun suami yang bekerja sebagai buruh di pabrik untuk memenuhi kebutuhan sehari-hari juga harus memperhatikan tumbuh kembang sang anak. Dengan keluarga yang cenderung meluangkan waktu untuk anak dengan menanamkan nilai dan norma. Jadi dalam hal tersebut sebaiknya memaksimalkan quality time bersama keluarga menjadikan terciptanya keluarga yang memiliki ikatan emosional yang kuat dan memberikan intensitas waktu yang banyak dengan keluarga seperti orangtua dan anak.

Memberikan pengawasan kepada anak yang optimal, tidak semua keinginan anak harus dituruti terkadang anak juga harus diberikan pengertian. Memberikan pengertian dengan meluangkan waktu pada anak menumbuhkan interaksi secara langsung tidak hanya memlalui pengasuh ataupun anggota keluarga lain. Sebab interaksi secara langsung juga perlu dibandingkan dengan interaksi yang terjadi secara tidak langsung seperti menitipkan pesan kepada anak melalui anggota keluarga lain, pengasuh maupun tetangganya. Dengan interaksi secara langsung yang dilakukan orang tua ke anak, anak akan merasa diperhatikan dan merasa dekat dengan orang tua sehingga orang tua tetap memiliki peran tersebut

\section{DAFTAR PUSTAKA}

Agustin, Dyah Satya Yoga, dkk. (2015). Peran Keluarga Sangat Penting dalam Pendidikan Mental, Karakter serta Budi Pekerti Anak. Jurnal Sosial Humaniora 8 (1).

Agustini, Tita, and Retno Winarni. (2014). Industrialisasi Di Kabupaten Pasuruan Tahun 19922007. Publika $\quad$ Budaya 2 (1): 78-84. http://jurnal.unej.ac.id/index.php/PB/article/download/583/406.

Goode, William J. (1991). Sosiologi Keluarga. Bumi Aksara : Jakarta. Hal 3.

Hermawati. (2018). Perunahan Pola Kehidupan Keluarga di Era Industri. Jurnal Bimbingan dan Konseling Islam 4 (1).

Ihrom. (2004). Bunga Rampai Sosiologi Keluarga. Jakarta : Yayasan Obor Indonesia. Hal 30.Jannah, Raodatul, and M. Ridwan Said Ahmad. (2018). Dampak Keluarga Bercerai Terhadap Pendidikan Anak Di Kelurahan Bonto-Bontoa Kabupaten Gowa. Jurnal Sosialisasi Pendidikan Sosiologi-FIS UNM 5 (1): 126-31. 
Mardiyanti, Ani. (2015). Peran Keluarga dan Masyarakat dalam Perlingdungan Anak Mengurangi Tindak Kekerasan. Jurnal PKS 14 (4).

Masitha, Dewi. (2018). Makna Pendidikan Formal Bagi Orang Tua Siswa di Pulau Poteran. Jurnal Paradigma 4 (1).

Mulyadi, Mohammad. (2015). Perubahan Sosial Masyarakat Agraris ke Masyarakat Industri dalam Pembangunan Masyarakat di Kecamatan Tamalate Kota Makasar. Jurnal Kemendagri.

Prasanti, Ditha. (2016). Perubahan Media Komunikasi Dalam Pola Komunikasi Keluarga Di Era Digital. Jurnal Commed 1 (1): 69-91.

Prasetyo, Hoedi dan Sutopo,Wahyudi, (2018). Industri 4.0: Telaah Klasifikasi Aspek dan Arah Perkembangan Riset.J@ti Undip: Jurnal Teknik Industri 13 (1): 17-26.

Pratiwi, Dessy Fitri. Dkk. (2015). Keberfungsian Sosial Buruh Perempuan pada Sektor Industri dalam Keluarga. Prosiding ks: riset \& pkm. Vol 2. No. 2.

Rahmaita, dkk. (2016). Pengaruh Tugas dan Perkembangan Keluarga Terhadap Kepuasan Perkawinan Ibu yang Baru Memiliki Anan Pertama. Jurnal IImu Keluarga \& Konsumeni 9 (1).

Rochaniningsih, Nunung Sri. (2014). Dampak Pergeseran Peran Dan Fungsi Keluarga Pada Perilaku Menyimpang Remaja. Jurnal Pembangunan Pendidikan: Fondasi Dan Aplikasi 2 (1): 59-71. https://doi.org/10.21831/jppfa.v2i1.2618.

Ritzer, George. (2010). Teori Sosiologi Modern. Jakarta : Kencana. Hal 257-261.

Rustina. (2014). Keluarga Dalam Kajian Sosiologi. Musawa 06 (2): 287-322.

Rochaniningsih, N.S. (2014). DAMPAK PERGESERAN PERAN DAN FUNGSI KELUARGA PADA PERILAKU MENYIMPANG REMAJA. Jurnal Pembangunan Pendidikan: Fondasi dan Aplikasi. Volume 2, Nomor 1, 2014

Talopo, Rahmawati, Hasan Pribadi, and Asep Topan. (2018). Disfungsi Keluarga Dalam Pendidikan Formal Anak (Studi Kasus Desa Durian Mas Kecamatan Kota Padang, Kabupaten Rejang Lebong, Bengkulu). Jurnal Sosiologi Nusantara 4 (1): 10-20.

Siswanto. (2007). Kesehatan Mental; Konsep Cakupan dan Perkembangannya. Yogyakarta: penerbit C.V Andi Offset. Hal 43Soekanto, Soerjono.(1992). Sosiologi keluarga tentang ikhwal keluarga remaja dan anak. PT rineka cipta : Jakarta. Hal 23.

Solikhah, A., Mudzakkir, M. (2015). Pergeseran Nilai Sosialisasi Primer Pada Keluarga Double Income Di Sidoarjo. Paradigma. Volume 03 Nomer 03.

Sosrodiharjo, Soedjipto. (1991). Transformasi Sosial Menuju Masyarakat Industri. Tiara Wacana : Yogyakarta. Hal 13.

Subadi, Tjipto. (2008). Sosiologi. BP - FKIP UMS : Surakarta. Hal 20

Suryadi. (2015). Ancaman Perselingkuhan Dalam Keutuhan Keluarga Bahagia. Konseling Religi: Jurnal Bimbingan Konseling Islam 6 (1): 126. 